
A.M. Antonenko ${ }^{1}$, O.P. Vavrinevych ${ }^{1}$, S.T. Omelchuk ${ }^{2}$, B.I. Shpak ${ }^{3}$

\title{
HYGIENIC SUBSTANTIATION OF CALCULATING MODELS FOR PREDICTING TOXICITY OF DIFFERENT CLASSES INSECTICIDES (first part)
}

\author{
Bogomolets National Medical University \\ Hygiene and ecology department $N 1^{1}$ \\ Hygiene and ecology institute ${ }^{2}$ \\ Peremohy av., 34, Kyiv, 03057, Ukraine \\ «Syngenta» $L C C^{3}$ \\ Kozatska str., 120/4, Kyiv, 02000, Ukraine \\ Наиіональний медичний університет ім. О.О. Богомольия \\ Кафедра гігієни та екології № $1^{1}$ \\ Інститут гігісни та екології ${ }^{2}$ \\ пр. Премоги, 34, Київ, 03057, Україна \\ ООО «Сингента» ${ }^{3}$ \\ вул. Козаџька, 120/4, Київ, 02000, Україна \\ e-mail: antonenko1985@ukr.net
}

Цитування: Медичні перспективи. 2019. Т. 24, № 3. С. 106-112

Cited: Medicni perspektivi. 2019;24(3):106-112

Key words: insecticide, toxicology, calculation models, regression equations

Ключові слова: інсектицид, токсикологія, розрахункові моделі, рівняння регресії

Ключевые слова: инсектицид, токсикология, расчетные модели, уравнение регрессии

\begin{abstract}
Hygienic substantiation of calculating models for predicting toxicity of different classes insecticides (first part). Antonenko A.M., Vavrinevych O.P., Omelchuk S.T., Shpak B.I. This work is the first part of our study to develop alternative experimental mathematic models for predicting toxicity of insecticides. In the first stage, calculations will be carried out and the most reliable models will be proposed. In the second-a statistical analysis and comparative estimation of the toxicometric parameters obtained experimentally and calculated according to the proposed equations. The purpose of the research is the scientific substantiation of the calculation models for predicting toxicity of insecticides of different classes. Data on the physico-chemical properties and toxicometry parameters of fungicides are taken from the PPDB pesticides database. Insecticides of such chemical classes as derivatives of tetram and tetronic acids, benzoylureas, carbamates, neonicotinoids, pyrethroids, organophosphorus compounds, avermectins were selected for analysis. It has been established that there is a significant positive correlation between NO(A)EL in the chronic experiment of all insecticides, the median lethal doses at oral administration (LD $D_{50}$ per os) of pyrithoids and neonicotinoids, and the molecular weight (at $p<0.05$ ). There is a significant negative correlation between the toxicometry parameters of all insecticides and their individual groups (pyrithoids, neonicotinoids, organophosphorus compounds) and melting temperature and the octanol-water partition coefficient, $\log P_{o / w}($ at $p<0.05)$. It is proved that the proposed calculation models for predicting insecticide hazards are adequate according to Fisher's criterion, and the coefficients of regression equations are reliable according to Student's criterion $(p<0,05)$.
\end{abstract}

Реферат. Гігіснічне обгрунтування розрахункових моделей прогнозування токсичності інсектицидів різних класів (перша частина). Антоненко А.М., Вавріневич О.П., Омельчук С.Т., Шпак Б.І. Ця робота $\epsilon$ першою частиною нашого дослідження з розробки альтернативних експериментальних математичних моделей для прогнозування токсичності інсектицидів. На першому етапі будуть проведені розрахунки й запропоновані найбільш надійні моделі. На другому - буде проведено статистичний аналіз і порівняльна оцінка токсикометричних параметрів, отриманих експериментально і розрахованих за пропонованими рівняннями. Метою дослідження було наукове обтрунтування розрахункових моделей прогнозування токсичності інсектицидів різних класів. Дані про фізико-хімічні властивості та токсикометричні параметри фунгіцидів взяті з бази даних пестицидів РРDВ. Для аналізу були обрані інсектициди таких хімічних класів: похідні тетрамової і тетронової кислот, бензоїлсечовини, карбамати, неонікотиноїди, піретроїди, фосфорорганічні сполуки, авермектини. Встановлено, щчо існує достовірний прямий корелячійний зв'язок між NO(A)EL y хронічному експерименті всіх інсектицидів, середньосмертельними дозами при пероральному надходженні (ЛД, 5 реr os) піритоїдів і неонікотиноїдів і молекулярною масою. Існує достовірний негативний корелячійний 
зв'язок між параметрами токсикометрії всіх інсектиџидів та їх окремих груп (піритоїди, неонікотиноїди, фосфорорганічні сполуки) $i$ температурою плавлення та коефіцієнтом розподілу октанол-вода, log $P_{\text {о/w. }}$ Доведено, щзо запропоновані розрахункові моделі для прогнозування небезпеки інсектицидів $\epsilon$ адекватними за критерієм Фішера, а коефіиієнти рівнянь регресії є надійними за критерієм Стьюдента.

Today's pesticides are a very effective in increasing yields, but at the same time a serious risk factor for human health because of contamination of environmental objects [6,7]. Methods for determining the toxicological parameters of pesticides are long-term, labor-intensive and require significant financial and resource costs $[9,14]$. In solving this problem, the important role is played by methods of mathematical modeling and predicting of toxicity of xenobiotics, the results of which can be used both for substantiation of toxicological parameters, and at the stage of experiment planning, this will reduce the probability of error and reduce the duration of the study [9].

Foreign laboratories and institutes have been using modeling dependence of toxicometric parameters on the physico-chemical properties of xenobiotics for a long time $[5,11]$.

In Ukraine today, there are such models for fungicides and herbicides proposed by the specialists of the Hygiene and Ecology Institute of Bogomolets National Medical University [10, 15], as for insecticides, only attempts were made to develop hazard prediction models for prognosis of the risk of neonicotinoid insecticides [2].

This work is the first part of our study to develop alternative experimental mathematic models for predicting toxicity of insecticides. At the first stage, calculations will be carried out and the most reliable models will be proposed. At the second - a statistical analysis and comparative estimation of the toxicometric parameters obtained experimentally and calculated according to the proposed equations.

The purpose of the research is the scientific substantiation of the calculation models for predicting toxicity of insecticides of different classes.

\section{MATERIALS AND METHODS OF RESEARCH}

For the development and substantiation of the calculation models in the hygienic assessment of the studied insecticides hazard, an array of experimentally established values of $\mathrm{LD}_{50}$ (median lethal dose) after oral and percutaneous administration, $\mathrm{LC}_{50}$ (median lethal concentration) at inhalation and NO(A)EL (no observed (adverse) effect level) [12], physical and chemical properties (molecular mass, water solubility, vapor pressure, melting point, octanol-water partition coefficient $\left(\operatorname{LogP} \quad \mathrm{K}_{\mathrm{o} / \mathrm{w}}\right)$, surface tension) was taken. Data on the physicochemical properties of fungicides are taken from the PPDB pesticides database [12].
For analysis, we selected insecticides of chemical classes the most widely used in the world $[4,8]: 3$ compounds of derivatives of tetram and tetronic acids class (spiromesifen, spirodiclofen and spirotetramat); 3 benzoyl-ureas (diflubenzuron, navalurone, teflubenzuron); 4 compounds of the carbamates class (carbosulfan, methomyl, carbaryl, phenoxycarb); 5 substances of the neonicotinoid class (acetamiprid, thiacloprid, imidacloprid, thiamethoxam, clothianidin); 12 active ingridients - pyrethroids (zeta-cypermethrin, lambda-cyhalothrin, beta-cyflutrin, tau-fluvalinate, gamma-cyhalothrin, tefluthrin, bifentrine, esfenvalerate, beta-cypermethrin, cypermethrin, deltamethrin, alpha-cypermethrin); 6 organophosphorus compounds (chlorpyrifos-methyl, dimethoate, malathion, fosalon, pyrimifos-methyl, phenythrothion); 2 avermectins (abamectin and emamectin benzoate).

Statistical processing of the results was performed using the package of licensed statistical software IBM SPSS StatisticsBase v.22 and MS Excel. Correlation and regression analyses were carried out, taking into account the determination coefficient, which most closely approximates the connection between the selected toxicological parameters and physical-chemical properties. The significance of the obtained regression equations was checked by Fisher's F-criterion, the reliability of individual coefficients in the regression equation $(\mathrm{a}, \mathrm{b})$ according to the Student's t-criterion.

\section{RESULTS AND DISCUSSION}

Initially, by the Pirson method we analyzed the correlation relations between the physical and chemical properties of the derivatives of tetram and tetronic acids, benzoylureas, carbamates, neonicotinoids, pyrethroids, organophosphorus compounds, avermectins and their parameters of toxicometry. Statistically significant results are given in Table 1.

The results of the correlation-regression analysis revealed a reverse (negative) correlation between the "octanol-water" partition coefficient and $\mathrm{LD}_{50}$ percut. and $\mathrm{NO}(\mathrm{A}) \mathrm{EL}$ of all insecticides and $\mathrm{LD}_{50}$ per os of neonicotinoids $(r=-0.47 ;-0.39$ and -0.83 , respectively, at $\mathrm{p}<0.05$ ) on the array of 35,28 and 5 active ingredients of the corresponding classes. Using the determination coefficient $\left(\mathrm{R}^{2}\right)$, the proportion of the effect of the investigated factor on the parameters of toxicometry was determined and it was established that the share of influence of the 
«octanol-water» distribution coefficients was 22.1; 15.0 and $69.0 \%$, respectively.

The obtained results can be explained by the fact that fat-soluble compounds are slowly metabolized and eliminated from the body, tend to accumulate [13], this increases their toxicity and reduces $\mathrm{NO}(\mathrm{A}) \mathrm{EL}$ and $\mathrm{LD}_{50}$. This dependence is typical, since $\log \mathrm{P}_{\mathrm{o} / \mathrm{w}}$ is an indicator of the bioavailability of toxic substances [1, 3]. At the same time, for herbicides, the opposite dependence was found: their toxic manifestations decreased with increasing log $\mathrm{P}_{\mathrm{o} / \mathrm{w}}$, which can be explained by the presence of alternative routes of herbicide penetration into the organism due to slightly lower molecular weight and higher solubility in water [10].

There is an inverse (negative) correlation between the melting point and $\mathrm{LC}_{50}$ in inhalation and NO(A)EL of organophosphorus compounds, as well as $\mathrm{LD}_{50}$ per os of pyrethroids $(\mathrm{r}=-0.88 ;-0.92$ and 0.62 , respectively at $p<0,05$ ) on an array of 5 and 12 active substances of the corresponding classes. Percentage of impact of the melting temperature on the parameters of toxicometry is quite high and makes $78.0 ; 84.0$ and $38.8 \%$, respectively.

Table 1

\section{Correlation between the parameters of toxicometry and physical and chemical properties of studied insecticides}

\begin{tabular}{|c|c|c|c|c|c|}
\hline \multirow{2}{*}{ Chemical class } & \multirow{2}{*}{ Resulting variable } & \multirow{2}{*}{ Factor variable } & \multicolumn{3}{|c|}{ Statistical parameters* } \\
\hline & & & $\begin{array}{l}\text { correlation } \\
\text { coefficient }\end{array}$ & $\begin{array}{l}\text { determination } \\
\text { coefficient, } \%\end{array}$ & $\mathbf{n}$ \\
\hline \multirow[t]{3}{*}{ Insecticides } & $\mathrm{LD}_{50}$ percut., mg/kg & $\log \mathbf{P}_{\mathrm{o} / \mathrm{w}}$ & -0.47 & 22.1 & 35 \\
\hline & NO(A)EL, mg/kg & & -0.39 & 15.0 & 28 \\
\hline & NO(A)EL, mg/kg & molecular weight & 0.51 & 25.8 & 27 \\
\hline \multirow[t]{2}{*}{ Pyrethro-ids } & $\mathrm{LD}_{50}$ per os, $\mathrm{mg} / \mathrm{kg}$ & melting temperature, ${ }^{\circ} \mathrm{C}$ & -0.62 & 38.8 & 12 \\
\hline & & molecular weight & 0.72 & 51.3 & 11 \\
\hline \multirow{2}{*}{$\begin{array}{l}\text { Oganophosphor } \\
\text { us compounds }\end{array}$} & NO(A)EL, mg/kg & melting temperature,${ }^{\circ} \mathrm{C}$ & -0.92 & 84.0 & 5 \\
\hline & $\mathrm{LC}_{50}$ inhal., $\mathrm{mg} / \mathrm{m}^{3}$ & & -0.88 & 78.0 & 5 \\
\hline \multirow[t]{2}{*}{ Neoni-cotinoids } & $\mathrm{LD}_{50}$ per os, mg/kg & $\log P_{o / w}$ & -0.83 & 69.0 & 5 \\
\hline & & molecular weight & 0.85 & 71.6 & 5 \\
\hline
\end{tabular}

Notes: «*» - significant results are given (at $\mathrm{p}<0,05) ; \mathrm{n}$ - number of observations; $\log \mathrm{P}_{\mathrm{o} / \mathrm{w}}$ - the logarithm of octanol-water partition coefficient; $\mathrm{LD}_{50}$ per os - median lethal dose after oral consumption; $\mathrm{LD}_{50}$ per cut - median-lethal dose when applied to the skin; $\mathrm{LC}_{50}$ inhal. - median lethal concentration at inhalation; NO(A)EL - no observed (adverse) effect level.

A similar correlation of the melting point with the parameters of toxicometry (with an increase in the melting point $\mathrm{LD}_{50}$ per os and inhal., $\mathrm{NO}(\mathrm{A}) \mathrm{EL}$, values decrease, it means that toxicity of these compounds increases) was also found in the chemical class of herbicides pyrazoles-triketones [10]. One of the reasons for this effect may be the need for a higher temperature for the degradation of the mentioned compounds. At body temperature they retain their initial physical and chemical properties longer and, accordingly, have more time to implement toxic manifestations.

Positive (direct) correlation was found between molecular weight and $\mathrm{LD}_{50}$ per os of pyrethroids $(n=11)$ and neonicotinoids $(n=5)$; NO(A)EL of all insecticides without phosphorus compounds $(n=27)$ $(r=0.72 ; 0.85$ and 0.51 , respectively, at $\mathrm{p}<0.05)$. The proportion of the influence of the molecular weight, as well as the melting point, is quite high and amounts to $51.3 ; 71.6$ and $25.8 \%$, respectively. 
Detected dependence is due to the fact that compounds with very high molecular weight poorly penetrate into the body, in contrast to low molecular weight compounds that easily pass through histohemic barriers $[1,3,13]$. It should be noted that for fungicides, the relationship between molecular weight and toxicometry parameters is reversible, since most of them, in contrast to insecticides, form isomers that greatly increase the specificity of their action and toxicity [15].

The next step was to carry out a regression analysis with the verification of the obtained equations (tabl. 2, 3) according to Fisher's F statistics, and separate coefficients in the regression equations $(\mathrm{a}, \mathrm{b})$ - according to Student's t-criterion.

Models of predicting insecticides hazard (linear equations)

\begin{tabular}{|c|c|c|c|c|c|c|c|c|c|}
\hline \multirow{3}{*}{$\begin{array}{l}\text { Chemical } \\
\text { class }\end{array}$} & \multirow{3}{*}{$\mathbf{n}$} & \multirow{3}{*}{$\mathbf{N}$} & \multirow{3}{*}{ Regression equations } & \multicolumn{3}{|c|}{ Model adequacy indices } & \multicolumn{3}{|c|}{$\begin{array}{l}\text { Coefficients reliability } \\
\text { indices }\end{array}$} \\
\hline & & & & \multicolumn{2}{|c|}{ Fisher's criterion } & \multirow{2}{*}{$\begin{array}{l}\text { Approxim } \\
\text { ation } \\
\text { accuracy } \\
\left(\mathbf{R}^{2}\right)\end{array}$} & a & b & \multirow{2}{*}{$\mathbf{t}_{\mathrm{kp} .}{ }^{* *}$} \\
\hline & & & & F & $\mathbf{F}_{\text {кр. }} * *$ & & $\mathbf{t}$ & $\mathbf{t}$ & \\
\hline \multirow[t]{3}{*}{ Insecticides } & 35 & 1 & $\mathrm{LD}_{50}$ percut. $=3.1136 \mathrm{X}_{1}+3371$ & 9.34* & 4.15 & 0.003 & $3.51^{*}$ & 3.06* & 2.04 \\
\hline & 27 & 2 & 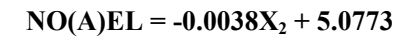 & $8.68 *$ & 4.24 & 0.113 & $4.26 *$ & $2.95 *$ & 2.06 \\
\hline & 28 & 3 & $\operatorname{NO}(A) E L=-0.6959 X_{1}+6.4644$ & $4.58 *$ & 4.22 & 0.150 & 4.10* & 2.14* & 1.71 \\
\hline \multirow[t]{2}{*}{ Pyrethroids } & 11 & 4 & $L D_{50}$ per os $=4.1975 X_{2}-1690.1$ & $9.48 *$ & 5.12 & 0.513 & $2.86 *$ & $3.08^{*}$ & 2.26 \\
\hline & 12 & 5 & LD ${ }_{50}$ per os $=-2.6492 X_{3}+268.28$ & $6.33 *$ & 4.96 & 0.388 & $3.99 *$ & $2.52 *$ & 2.23 \\
\hline \multirow{2}{*}{$\begin{array}{l}\text { Oganophos- } \\
\text { phorus } \\
\text { compounds }\end{array}$} & 5 & 6 & $\operatorname{NO}(A) E L=-0.405 X_{3}+18.196$ & $15.69 *$ & 10.13 & 0.840 & 4.53* & 3.96* & 3.18 \\
\hline & 5 & 7 & $L C_{50}$ inhal. $=-0.0541 X_{3}+3.7237$ & $10.64^{*}$ & 10.13 & 0.913 & $6.15 *$ & $3.26^{*}$ & 3.18 \\
\hline \multirow[t]{2}{*}{$\begin{array}{l}\text { Neonico- } \\
\text { tinoids }\end{array}$} & 5 & 8 & LD $_{50}$ per os $=21.016 \mathrm{X}_{2}-4844.9$ & 7.57 & 10.13 & 0.716 & 2.48 & 2.75 & 3.18 \\
\hline & 5 & 9 & $L D_{50}$ per os $=-981.92 X_{1}+1172.1$ & 6.66 & 10.13 & 0.690 & 3.74* & 2.58 & 3.18 \\
\hline
\end{tabular}

Notes: $\left\langle{ }^{*}\right\rangle-$ statistical significant results; $\left\langle{ }^{*}{ }^{*} »-\right.$ at $\mathrm{p}=0.05$ and $\left.\mathrm{k}_{1}=1, \mathrm{k}_{2}=\mathrm{n}-2\right) ; \mathrm{n}$ - number of observations; $\mathrm{X}_{1}-$ octanol-water partition coefficient, $\log \mathrm{P}_{\mathrm{o} / \mathrm{w}} ; \mathrm{X}_{2}-$ molecular weight; $\mathrm{X}_{3}-$ melting temperature, ${ }^{\circ} \mathrm{C}$.

The results of the regression analysis given in Table 2 indicate that the 4 derived linear regression equations N 1-14 are adequate according to Fisher's criterion $(\mathrm{p}<0.05)$.

The assessment of coefficients «a» and «b» reliability showed that in all regression equations, they are significant according to Student's t-criterion $(p<0,05)$, except for the equations N 8 and 9 . In this equations, the coefficients «a» and / or $\langle\mathrm{b}$ » were unreliable, since the absolute value of the criterion $t$ is less than $t_{\text {cr, }}$, which may be due to a small number of observations $(\mathrm{n}=5)$.

We also used the exponential, logarithmic, polynomial and step functions in addition to the linear one. In Table 3 the obtained mathematical models are given. Except for the formulas 10, 11, $17,18,19$, the rest showed rather high indicators of the adequacy of the model by the coefficients of approximation. 
Table 3

Models of predicting insecticides hazard (nonlinear equations)

\begin{tabular}{|c|c|c|c|c|}
\hline Chemical class & $\mathbf{n}$ & $\mathbf{N}$ & Regression equation & Model adequacy index $\left(\mathbf{R}^{2}\right)$ \\
\hline \multirow[t]{10}{*}{ Insecticides } & 35 & 10 & $L_{50}$ percut. $=2247.1 \mathrm{e}^{-0.037 \mathrm{x}}$ & $\mathbf{0 . 0 1 5}$ \\
\hline & 35 & 11 & ${ }^{L} D_{50}$ percut. $=59.94 X_{1}^{2}-418.17 X_{1}+2731$ & 0.044 \\
\hline & 27 & 12 & $\operatorname{NO}(\mathrm{A}) E L=3.8947 \mathrm{e}^{-0.002 x_{2}}$ & 0.222 \\
\hline & 27 & 13 & $\operatorname{NO}(A) E L=-3.782 \ln \left(X_{2}\right)+25.928$ & 0.216 \\
\hline & 27 & 14 & $\mathrm{NO}(\mathrm{A}) E L=9572.6 \mathrm{X}_{2}^{-1.447}$ & 0.265 \\
\hline & 27 & 15 & $\operatorname{NO}(A) E L=9 \times 10^{-6} X_{2}{ }^{2}-0.0223 X_{2}+10.655$ & 0.273 \\
\hline & 28 & 16 & $\operatorname{NO}(A) E L=-0.1125 X_{1}^{2}+0.1261 X_{1}+5.5048$ & 0.165 \\
\hline & 28 & 17 & $\operatorname{NO}(A) E L=3.7507 \mathrm{e}^{-0.182 x_{1}}$ & 0.086 \\
\hline & 28 & 18 & $N O(A) E L=-0.404 \ln \left(X_{1}\right)+3.8851$ & 0.017 \\
\hline & 28 & 19 & $\operatorname{NO}(A) E L=1.7218 X_{1}^{-0.014}$ & 0.0002 \\
\hline \multirow[t]{6}{*}{ Pyrethroids } & 11 & 20 & $L D_{50}$ per os $=0.1234 X_{2}^{2}-108.4 X_{2}+23844$ & 0.818 \\
\hline & 11 & 21 & $\mathrm{LD}_{50}$ per os $=0.029 \mathrm{e}^{0.0184 \mathrm{x}}{ }_{2}$ & 0.300 \\
\hline & 11 & 22 & $\mathrm{LD}_{50}$ per os $=1864.9 \ln \left(\mathrm{X}_{2}\right)-11191$ & 0.490 \\
\hline & 11 & 23 & $\mathrm{LD}_{50}$ per os $=3 \times 10^{-20} \mathrm{X}_{2}^{8.1429}$ & 0.285 \\
\hline & 12 & 24 & $L D_{50}$ per os $=160.23 \mathrm{e}^{-0.012 x_{3}}$ & 0.248 \\
\hline & 12 & 25 & $\mathrm{LD}_{50}$ per os $=0.0418 \mathrm{X}_{3}^{2}-6.2181 \mathrm{X}_{3}+291.86$ & 0.520 \\
\hline \multirow{4}{*}{$\begin{array}{l}\text { Oganophos-phorus } \\
\text { compounds }\end{array}$} & 5 & 26 & $\operatorname{NO}(\mathrm{A}) E L=5.7067 \mathrm{e}^{-0.059 \mathrm{x}_{3}}$ & 0.696 \\
\hline & 5 & 27 & $\operatorname{NO}(A) E L=0.0104 X_{3}^{2}-0.7223 X_{3}+11.339$ & 0.996 \\
\hline & 5 & 28 & LC $_{50}$ inhal. $=0.0006 \mathrm{X}_{3}^{2}-0.073 \mathrm{X}_{3}+3.3139$ & 0.947 \\
\hline & 5 & 29 & $\mathrm{LC}_{50}$ inhal. $=3.2317 \mathrm{e}^{-0.022 \mathrm{x}}{ }_{3}$ & 0.754 \\
\hline \multirow[t]{6}{*}{ Neonicotinoids } & 5 & 30 & $L D_{50}$ per os $=0.4334 X_{2}^{2}-203.01 X_{2}+23888$ & 0.919 \\
\hline & 5 & 31 & $\mathrm{LD}_{50}$ per os $=0.0567 \mathrm{e}^{0.0338 \mathrm{x}}$ & 0.619 \\
\hline & 5 & 32 & $L_{50}$ per os $=5239.7 \ln (x)-28501$ & 0.676 \\
\hline & 5 & 33 & $L^{L} D_{50}$ per os $=1 E-18 x^{8.4697}$ & 0.592 \\
\hline & 5 & 34 & $L D_{50}$ per os $=1170.4 X_{1}^{2}-2217.4 X_{1}+1220.3$ & 0.890 \\
\hline & 5 & 35 & $\mathbf{L D}_{50}$ per os $=804.89 \mathrm{e}^{-1.424 \mathrm{x}}$ & 0.486 \\
\hline
\end{tabular}

Notes: $\mathrm{n}$ - number of observations; $\mathrm{X}_{1}-\log \mathrm{P}_{\mathrm{o} / \mathrm{w}} ; \mathrm{X}_{2}-$ molecular weight; $\mathrm{X}_{3}-$ melting temperature, ${ }^{\circ} \mathrm{C}$.

\section{CONCLUSIONS}

It has been established that there is a significant positive correlation between $\mathrm{NO}(\mathrm{A}) \mathrm{EL}$ in the chronic experiment of all insecticides, the median lethal doses in oral admission (LD50 per os) of pyrithoids and neonicotinoids, and the molecular weight (at $\mathrm{p}<0.05$ ). 
1. There is a significant negative correlation between the toxicometry parameters of all insecticides and their individual groups (pyrithoids, neonicotinoids, organophosphorus compounds) and the melting temperature and the octanol-water partition coefficient, $\log \mathrm{Po} / \mathrm{w}($ at $\mathrm{p}<0.05)$.
2. It is proved that the proposed calculation models for predicting insecticide hazards are adequate according to Fisher's criterion, and the coefficients of regression equations are reliable according to Student's criterion $(\mathrm{p}<0,05)$.

\section{REFERENCES}

1. Batyan AN, Frumin GT, Bazylev VN. [Basics of General and Environmental Toxicology]. S-Pb. SpetsLit. 2009;352. Russian.

2. Yermolova LV, Prodanchuk MG, Leposhkin IV. [Development of calculation models for forecasting the risk of neonicotinoid insecticides]. Sovremennye problemy toksikologii. 2007;1:27-29. Ukrainian.

3. [General toxicology]. Edited BA Kurlyandskiy, VA Filova. Moskva. Meditsina. 2003;608. Russian.

4. [List of pesticides and agrochemicals authorized for use in Ukraine. Official edition]. Kyiv, Yunivest Media. 2018;1036. Ukrainian.

5. Anton C. Modeling and simulation for toxicity assessment. Math Biosci Eng. 2017;14(3):581-606. doi: https://doi.org/10.3934/mbe.2017034

6. Stavnichenko PV, Novohatska LO, Antonenko AM, et al. Assessment of ecotoxicological hazard and risk of groundwater contamination with different groups of pesticides. Medicni perspektivi. 2017;XXII(2):119-25. doi: https://doi.org/10.26641/2307-0404.2017.2.109845

7. Novohatska OO, Stavnichenko PV, Kondratiuk MV, et al. Comparative hygienic evaluation of behavior of different pesticides groups in soil, prediction of risk of ground water contamination and its danger for human health in areas with irrigation farming. Rawal Medical Journal. 2018;43(1):129-36.

8. EU - Pesticides database: Maximum Residue Levels. [cited 2019.06.20] Available from: http://ec.europa.eu/food/plant/pesticides/max_residue_1 evels/index_en.htm
9. Knudsen TB, Keller DA, Sander M, et al. FutureTox II: in vitro data and in silico models for predictive toxicology. Toxicological Sciences. 2015;143(2):256-67. doi: https://doi.org/10.1093/toxsci/kfu234

10. Antonenko AM, Vavrinevych OP, Korshun MM, et al. Hygienic substantiation of calculation models for toxicity prognosis of different herbicides classes. Sbornik nauchnykh trudov «Zdorove i okruzhayushchaya sreda». 2018;28:168-75.

11. Norto Á, Sathis1 J, Webb S, et al. Mathematical Modelling of Chronic Drug Infusion for Toxicity Assessment. UK Mathematics-in-Medicine NC3Rs Study Group. 2013;25.

12. PPDB: Pesticides property database. [cited 2019.06.20]. Available from: http://www.rupest.ru/ppdb

13. Pradhan A, Markande SK, Kurre RK. Evaluation of impact of pesticides on the basis of their physicochemical properties. Journal of Industrial Pollution Control. 2014;30(2):223-6.

14. Raies AB, Bajic VB. In silico toxicology: computational methods for the prediction of chemical toxicity. Wiley Interdiscip Rev. Comput. Mol. Sci. 2016;6(2):14772. doi: https://doi.org/10.1002/wcms. 1240

15. Vavrinevych OP, Antonenko AM, Korshun MM, Omelchuk ST. Hygienic substantiation of calculating models for fungicides of different classes toxicity depend on their physical and chemical properties prognosis. Environment and health. 2017;4(84):52-57. doi: https://doi.org/10.21303/2585-663.2017.00441

\section{СПИСОК ЛІТЕРАТУРИ}

1. Батян А. Н., Фрумин Г. Т., Базылев В. Н. Основы общей и экологической токсикологии. СанктПетербург: СпецЛит, 2009. 352 с.

2. Срмолова Л. В., Проданчук М. Г., Лепьошкін І. В. Розробка розрахункових моделей прогнозу небезпечності неонікотиноїдних інсектицидів. Современные проблемы токсикологии. 2007. № 1. С. 27-29.

3. Общая токсикология / ред. Б. А. Курляндского, В. А.Филова. Москва: Медицина, 2003. 608 с.

4. Перелік пестицидів і агрохімікатів, дозволених до використання в Україні: офіційне видання. Київ: Юнівест Медіа, 2018. 1036 с.

5. Anton C. Modeling and simulation for toxicity assessment. Math Biosci Eng. 2017. Vol. 14, No. 3. P. 581-606. doi: https://doi.org/10.3934/mbe.2017034
6. Assessment of ecotoxicological hazard and risk of groundwater contamination with different groups of pesticides / P. V. Stavnichenko et al. Медичні перспективи. 2017. Том XXII, № 2. C. 119-125. DOI: https://doi.org/10.26641/2307-0404.2017.2.109845

7. Comparative hygienic evaluation of behavior of different pesticides groups in soil, prediction of risk of ground water contamination and its danger for human health in areas with irrigation farming / O. O. Novohatska et al. Rawal Med. J. 2018. Vol. 43, No. 1. P. 129-136.

8. EU - Pesticides database: Maximum Residue Levels.

URL:http://ec.europa.eu/food/plant/pesticides/max_residu e_levels/index_en.htm. (date of access 20.06.2019). 
9. FutureTox II: in vitro data and in silico models for predictive toxicology / T. B. Knudsen et al. Toxicological Sciences. 2015. Vol. 143, No. 2. P. 256267. DOI: https://doi.org/10.1093/toxsci/kfu234

10. Hygienic substantiation of calculation models for toxicity prognosis of different herbicides classes / A. M. Antonenko et al. Сборник научных трудов «Здоровье и окружающая среда». 2018. Вып. 28. С. 168-175.

11. Mathematical Modelling of Chronic Drug Infusion for Toxicity Assessment / Á. Norto et al. UK Mathematics-in-Medicine NC3Rs Study Group. 2013. 25 p.

12. PPDB: Pesticides property database. (date of access 20.06.2019). URL: http://www.rupest.ru/ppdb..

13. Pradhan A., Markande S. K., Kurre R. K. Evaluation of impact of pesticides on the basis of their physico- chemical properties. J. Industrial Pollution Control. 2014. Vool. 30, No. 2. P. 223-226.

14. Raies A. B., Bajic V. B. In silico toxicology: computational methods for the prediction of chemical toxicity. Wiley Interdiscip Rev. Comput. Mol. Sci. 2016. Vol. 6, No. 2. P. 147-172.

DOI: https://doi.org/10.1002/wcms. 1240

15. Vavrinevych O. P., Antonenko A. M., Korshun M. M., Omelchuk S. T. Hygienic substantiation of calculating models for fungicides of different classes toxicity depend on their physical and chemical properties prognosis. Довкілля $i$ здоров’я. 2017. Т. 84, № 4. С. 5257. DOI: https://doi.org/10.21303/2585-663.2017.00441

Стаття надійшла до редакції 24.06.2019 